\title{
Angina Ludovici. Case presentation
}

\author{
Mugurel Constantin Rusu ${ }^{1 *}$, Sorin Hostiuc ${ }^{2,3}$, Mihai Ceauşu $u^{4,5}$, Irina Rentea ${ }^{6}$ \\ From The 9th Edition of the Scientific Days of the National Institute for Infectious Diseases Prof Dr Matei Bals \\ Bucharest, Romania. 23-25 October 2013
}

\section{Background}

Angina Ludovici (Ludwig's angina) is a severe infection of the connective tissue from the floor of the mouth, usually occurring secondary to a tooth infection. Left untreated may cause an extrinsic obstruction of the superior respiratory tract.

\section{Case report}

The purpose of this paper is to present an atypical case of Ludwig's angina, whose initial presentation suggested a diagnosis of a large laryngeal tumor. The patient, 62 years old, without other known pathologies, came to the Emergency Room with severe dyspnea, dysphagia, high fever, and severe hypoxemia. It enters in respiratory arrest and dies less than 24 hours after the initial presentation. During autopsy were found signs of infection in the floor of the mouth, trachea, epiglottis, larynx, and adjacent tissues. The infective process lead to an erosion of a branch of the thyroid artery, leading to a hemorrhage in close contact with the larynx, that caused the pseudo-tumor pattern initially identified in the ER.
Published: 16 December 2013

doi:10.1186/1471-2334-13-S1-P42

Cite this article as: Rusu et al: Angina Ludovici. Case presentation. BMC Infectious Diseases 2013 13(Suppl 1):P42.

\begin{abstract}
Authors' details
${ }^{1}$ Faculty of Dental Medicine, Carol Davila University of Medicine and Pharmacy, Bucharest, Romania. ${ }^{2}$ Department of Legal Medicine and Bioethics, Carol Davila University of Medicine and Pharmacy, Bucharest, Romania. ${ }^{3}$ Department of Forensic Pathology, National Institute of Legal Medicine, Bucharest, Romania. ${ }^{4}$ Department of Pathology, Carol Davila University of Medicine and Pharmacy, Bucharest, Romania. ${ }^{5}$ Department of Pathology, National Institute of Legal Medicine, Bucharest, Romania. ${ }^{6}$ Department of Forensic Pathology, National Institute of Legal Medicine, Bucharest, Romania.
\end{abstract}

\footnotetext{
* Correspondence: anatomon@gmail.com

${ }^{1}$ Faculty of Dental Medicine, Carol Davila University of Medicine and Pharmacy, Bucharest, Romania

Full list of author information is available at the end of the article
}

Submit your next manuscript to BioMed Central and take full advantage of:

- Convenient online submission

- Thorough peer review

- No space constraints or color figure charges

- Immediate publication on acceptance

- Inclusion in PubMed, CAS, Scopus and Google Scholar

- Research which is freely available for redistribution

\section{() Biomed Central}

